\title{
Shelf sand banks and sand dune fields from the Volgian-Valanginian Raukelv Formation of Jameson Land, East Greenland
}

\author{
Finn Surlyk and Nanna Noe-Nygaard
}

The aims of the present study were: to interpret precisely the depositional environment of the coarsegrained, cross-bedded sandstones of the Raukelv Formation (Lower Volgian - Valanginian) of Jameson Land; to explain the upwards transition over a few metres from the underlying deep-shelf mudstones and turbiditic sandstones of the Hareelv Formation; to make precise correlations and comparison with the Hartz Fjeld Formation of Milne Land to suggest an alternative to the fan delta interpretation of Sykes \& Brand (1976) which was proved inadequate by Birkelund et al. (1984); and finally to place the Raukelv Formation better within the regional tectonic and provenance framework.

The Raukelv Formation was erected by Surlyk et al. (1973) for a sequence up to $300 \mathrm{~m}$ thick of very coarsegrained, cross-bedded sandstones of Early Volgian to Valanginian age. The formation crops out in southern Jameson Land where it forms the youngest preserved unit. Further details on lithology and biostratigraphy are given by Surlyk $(1973,1975)$ and Surlyk \& Zakharov (1982). The marine nature of the formation was clearly recognized and the bulk of the sequence was interpreted in terms of a marine shelf sandwave system, while a fan delta interpretation was suggested for the giant-scale cross-beds (Surlyk, 1975; Surlyk et al. 1981). A pure fan delta interpretation was presented by Sykes \& Brand (1976) for the lower Hartz Fjeld Formation, a lateral correlative occurring in Milne Land. The latter authors based their essentially subaerial environment interpretation on the occurrence of abundant rootlets extending downwards from the top surface of large to giant-scale cross-beds. This interpretation was later questioned by Birkelund et al. (1984) who demonstrated that the alleged rootlets were actually long vertical Uburrows Diplocraterion habichi of clear marine affinity. They furthermore stressed the abundance of marine invertebrate fossils occurring in the Hartz Fjeld sandstones.

The coarse-grained sandstones of the Raukelv Formation show spectacular examples of large and giantscale cross-bedding. The giant-scale cross-beds occur as single isolated sets $15-50 \mathrm{~m}$ thick, which can be followed over tens of kilometres. The cross-strata are sigmoidal and simple or compound, being internally composed of large-scale trough-shaped cross-beds. The set tops are glauconitized and burrowed by Diplocraterion habichi.
Cross-strata may also show glauconite impregnation. Transport direction was towards the east. A diverse marine fauna of bivalves, ammonites and crinoids characterizes the facies. The giant-scale cross-beds are separated by sheets of tabular to trough cross-bedded cosets $5-10 \mathrm{~m}$ thick. These units can also be followed laterally over tens of kilometres and the top of the co-sets is burrowed and impregnated with glauconite. They contain marine faunas showing high density and diversity. Transport direction was towards the south or, in rare cases, to the north. A few levels of bioturbated muddy siltstones occur between the coarse-structured sandstone sheets.

Deposition of the Raukelv Formation took place in a system of eastwards migrating sand banks. Bank construction was followed by mainly southwards migration of sand dune fields. The water depth was below fair weather wave base and rate of deposition was slow, reflected by the glauconitized omission surfaces separating the sand sheets.

The interpretation of the Raukelv Formation as representing sand banks and sand dune fields formed in a relatively deep water shelf environment allows a total reinterpretation of the correlative lower Hartz Fjeld Formation in Milne Land, and of isolated sets of giantscale cross-sets occurring in other Jurassic formations in East Greenland. Finally, the upwards transition over a few metres from the deep-shelf mudstones and turbiditic sandstones of the underlying Hareelv Formation to the Raukelv Formation does not require a sea-level drop of several hundred metres as would have been the case if the latter formation was of fan delta or very shallow marine origin.

Acknowledgements. This study was undertaken while Surlyk was recipient of a research professorship awarded by the Danish Natural Science Research Council.

\section{References}

Birkelund, T., Callomon, J. H. \& Fürsich, F. T. 1984: The stratigraphy of the Upper Jurassic and Lower Cretaceous sediments of Milne Land, central East Greenland. Bull. Grønlands geol. Unders. 147, 1-56.

Surlyk, F. 1973: The Jurassic-Cretaceous boundary in Jameson Land, East Greenland. In Casey, R. \& Rawson, P. F. (edit.) The Boreal Lower Cretaceous. Geol. J. Spec. Iss., 5, 81-100. 
Surlyk, F. 1975: Block faulting and associated marine sedimentation at the Jurassic-Cretaceous boundary, East Greenland. In Finstad, K. G. \& Selley, R. C. (edit.) Jurassic northern North Sea symposium 1975 (JNNSS-75). Norwegian Petroleum Society, JNNSS/7, 1-31.

Surlyk, F., Callomon, J. H., Bromley, R. G. \& Birkelund, T. 1973: Stratigraphy of the Jurassic - Lower Cretaceous sediments of Jameson Land and Scoresby Land, East Greenland. Bull. Gronlands geol. Unders. 105, 1-76.

Surlyk, F., Clemmensen, L. B. \& Larsen, H. C. 1981: PostPaleozoic evolution of the East Greenland continental mar- gin. In Kerr, J. W. \& Ferguson, A. J. (edit.) Geology of the North Atlantic borderlands. Mem. Can. Soc. Petrol. Geol. 7, 611-645.

Surlyk, F. \& Zakharov, V. A. 1982: Buchiid bivalves from the Upper Jurassic and Lower Cretaceous of East Greenland. Palaeontology 25, 727-753.

Sykes, R. M. \& Brand, R. P. 1976: Fan-delta sedimentation: an example from the late Jurassic - early Cretaceous of Milne Land, central East Greenland. Geologie en Mijnbouw 55, 195-203.
F. S.,

Grønlands Geologiske Undersøgelse,

$\emptyset$ ster Voldgade 10 ,

$D K-1350$ København $K$,

Danmark.
N. N.-N., Inst. for Historisk Geologi og Palaontologi, $\emptyset$ ster Voldgade 10, $D K-1350$ København $K$, Danmark.

\title{
Sedimentological studies of the Upper Triassic to Lower Jurassic succession in the Jameson Land Basin, central East Greenland
}

\author{
Gregers Dam
}

Sedimentological studies of the Upper Triassic to Lower Jurassic succession in central East Greenland were initiated in 1987 as a three-year research fellowship programme supported by British Petroleum Development, London (Dam, 1988). The study is primarily a lithofacies analysis, but ichnology, palynology sourcerock analysis, porosity/permeability analysis and diagenetic studies are also included in the programme. The stratigraphic interval includes the Kap Stewart and Neill Klinter Formations which have many features in common with stratigraphically equivalent formations in offshore mid- and northern Norway that form some of the most important potential petroleum reservoirs in these areas.

The field work in 1988 was carried out by the author accompanied by A. Boesen, and lasted for 7 weeks from late June to late August but was impeded in a threeweek period by bad weather in the region.

The 1988 activities were concentrated in three main areas; along the west coast of Hurry Inlet, in Lepidopteriselv and Liaselv just west of Carlsberg Fjord, and in Ranunkeldal, a tributary valley to Schuchert Dal (fig. 1). Sedimentological studies involved detailed lithofacies and ichnofacies analyses as well as sampling for palynofacies analyses, source rock analyses and reservoir rock properties.

\section{Geological setting}

The sediments of the Kap Stewart and Neill Klinter Formations were laid down in the Jameson Land Basin in central East Greenland, where they constitute the lowermost two formations of the Jameson Land Group (Surlyk et al., 1973). In age the formations span most of the Rhaetian-Toarcian interval. Their setting in the Jameson Land basin was reviewed by Dam (1988).

\section{Kap Stewart Formation}

Seven facies associations are here recognized in the Kap Stewart Formation:

(1) Lacustrine (prodelta) association; (2) Interdistributary bay association; (3) Longshore directed shoal association; (4) Beach face association; (5) Distributary channel association; (6) Interdistributary area association; (7) Delta abandonment association.

Vertical and lateral distributions of environments. Along Hurry Inlet in the southeastern part of the basin the Kap Stewart Formation is approximately $200 \mathrm{~m}$ thick. In this area Harris (1937) subdivided the formation into an upper 'plant-bearing-series' and a lower 'barren sandstone'. Although this division has not been adopted in recent literature (Surlyk et al., 1973; Pe- 